\title{
The Impact Of Inflation On Financial Sector Development: Experience From Zambia
}

\author{
Nicholas M. Odhiambo, University of South Africa, South Africa
}

\begin{abstract}
This study examines the impact of inflation on financial development in Zambia during the period between 1980 and 2011. The study attempts to answer two critical questions: 1) Is there a longrun relationship between inflation and financial sector development in Zambia? 2) Does inflation in Zambia have any negative effect on financial sector development? The study uses the recently developed ARDL-bounds testing approach to examine this linkage. In order to address the problem of omission of variable bias, the study incorporates other variables, such as government expenditure, trade volume and GDP per capita in the financial development model, alongside inflation - thereby, creating a simple multivariate model. Using the domestic credit to the private sector as a proxy for financial development, the study finds that there is a long-run relationship between inflation and financial development in Zambia. The study also finds that there is a distinctively negative relationship between inflation and financial development. The results apply, irrespective of whether the model is estimated in the short run or in the long run.
\end{abstract}

Keywords: Africa; Zambia; Inflation; Financial Sector Development

\section{INTRODUCTION}

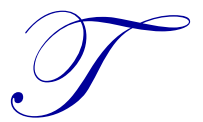

he relationship between inflation and financial development has been a subject of intense debate among macroeconomists in recent years. Studies done by Boyd et al. (2001) and Haslag and Koo (1999) show that inflation is associated with financial repression, and that the financial sector becomes less developed as inflation increases, especially when the average inflation rate is very high. In other words, the relationship between inflation and financial development is a non-linear one. There is a threshold level of inflation below which inflation has a positive effect on financial depth, but above which the effect turns negative (see Khan et al., 2001). Khan et al. (2001), for example, while using a large cross-country sample, find empirical support for the existence of such a threshold. Their estimates indicate that the threshold level of inflation is generally about 3 - 6 per cent per annum, depending on the specific measure of financial depth that is utilized.

There has also been an argument that inflation adversely affects the holding of all classes of financial assets, including narrow money. In addition, it has been argued that inflation tends to encourage the holding of currency, and to discourage the holding of quasi-money (see Odhiambo, 2005; Ikhide, 1992). According to English (1999), a higher inflation rate encourages households to substitute purchased transaction services for money balances, thereby boosting the financial sector. In this way, inflation may have a positive impact on financial development. Inflation also creates uncertainty and financial market frictions, which make the financial system inefficient in allocating resources (see Huybens and Smith, 1998; 1999; Boyd and Smith, 1998).

Unfortunately, very few studies have been conducted in sub-Saharan African countries - where inflation is at its highest. In addition, some of the previous studies somewhat over-relied on the cross-sectional data, which may not have satisfactorily addressed the country-specific issues. The current study, therefore, attempts to examine the dynamic linkage between inflation and financial development in Zambia - using the ARDL-bounds test. In order to examine this linkage, we regress the financial development variable on inflation, per capita GDP, government expenditure as a percentage of GDP, and trade as a percentage of GDP.

Copyright, Odhiambo 2012

(C) 2012 The Clute Institute http://www.cluteinstitute.com/ 
The rest of the paper is structured as follows: Section 2 discusses the dynamics of inflation and financial development in Zambia. Section 3 deals with the empirical model specification, estimation techniques and analysis of the empirical results. Section 4 concludes the study.

\section{INFLATION DYNAMICS AND FINANCIAL SECTOR DEVELOPMENT IN ZAMBIA}

Since the 1990s, Zambian monetary policy has been attaining macroeconomic stability through price stability, exchange rate stability, as well as financial system stability. On the price stability front, the current goal of the monetary policy has been to attain a single-digit inflation rate. Unfortunately, the country's efforts to sustain this single-digit inflation rate have been hindered by the high international oil prices, which are beyond the control of the Zambian monetary policy. In addition, the underdeveloped and fragmented nature of the financial system inhibits the effectiveness of the monetary policy.

Other factors that have contributed to the high rate of inflation in Zambia include deteriorating terms of trade due to slumps in copper prices during the period 2008 and 2009, exchange rate pressures, high public debt, and other supply factors, such as drought and floods. Also, due to low level of capital investment, the government has been forced to periodically issue bonds or expand the supply of money, in order to not only meet its recurrent and capital expenditure, but also to meet its debt obligations. Like many other sub-Saharan African countries, Zambia's external debt has increased significantly over the years. This has resulted in high interest rates, which have eventually fuelled inflation. The country's debt increased from US\$ 700 million in 1970, to US\$ 3.3 billion in 1980, to US\$ 6.7 Billion in 1991, and to US\$ 7.1 billion in 2004. In 1998, for example, the government had to draw down its foreign exchange reserves, in order to meet its foreign debt obligations. This negatively affected the exchange rate and inflation, and by 2000 the year-to-year inflation reached 32\%. Although the rate later decreased significantly to about $20 \%$, it later increased again to about $26.7 \%$ in 2002 . However, in 2007 the inflation decreased significantly to $8 \%$, which marked the lowest inflation rate in 30 years.

On the financial sector front, it is sufficient to state that the financial sector in Zambia, just like many other sub-Saharan African countries, is small and is still in its infancy stage. The activity among commercial banks is limited, and the derivatives market is virtually non-existent. The sector is basically a money market sector, with a very small capital market. It is also worth noting that the Zambian financial sector has undergone two major phases, since independence in 1964. The first phase is known as the pre-reform phase (or the Government's nationalisation phase); while the second phase is known as the post-reform phase.

During the pre-reform phase, the Government made efforts to nationalise many financial institutions, especially the non-bank financial institutions. During this phase, entry into the financial sector in Zambia was restricted. Instead, the government decided to establish financial institutions, such as the Development Bank of Zambia (DBZ), the Local Authority Superannuation Fund (LASF), and the Zambia Export and Import Bank. During this period, very few commercial banks were in operation, and their credit allocation was highly regulated. In addition, commercial banks were required by law to open branches in rural areas (see Simatele, 2004).

Unlike in the first phase, during the second phase, the liberalisation of the financial sector took place on a large scale. Specifically, the liberalisation of the financial sector, which took place in 1991, led to the entry of new financial institutions into the industry. Since then, the financial sector in Zambia has grown phenomenally. The financial sector currently comprises the central bank, 17 commercial banks, non-bank financial institutions comprising the three building societies, 16 microfinance institutions, the National Savings and Credit Bank (NSCB), the Development Bank of Zambia, the 40 Bureaus de Change, 10 leasing companies, insurance companies, and pension funds.

Notwithstanding the new entries into the financial sector since the onset of financial liberalisation, the Zambian financial system has remained relatively small and under-developed. For example, the monetisation ratio (i.e. the ratio of $\mathrm{M}_{2}$ to GDP) has been in the range of $15-20 \%$ over the last five years, compared with about 35\% recorded in the 1980s. Apart from the State-owned Zambian National Commercial Bank (ZNCB), the majority of the banks in Zambia are foreign-owned. Figures 1 and 2 show the trends of the CPI inflation rate and the domestic credit to the private sector (\% of GDP) during the periods 1980-2000 and 2000-2011, respectively. 


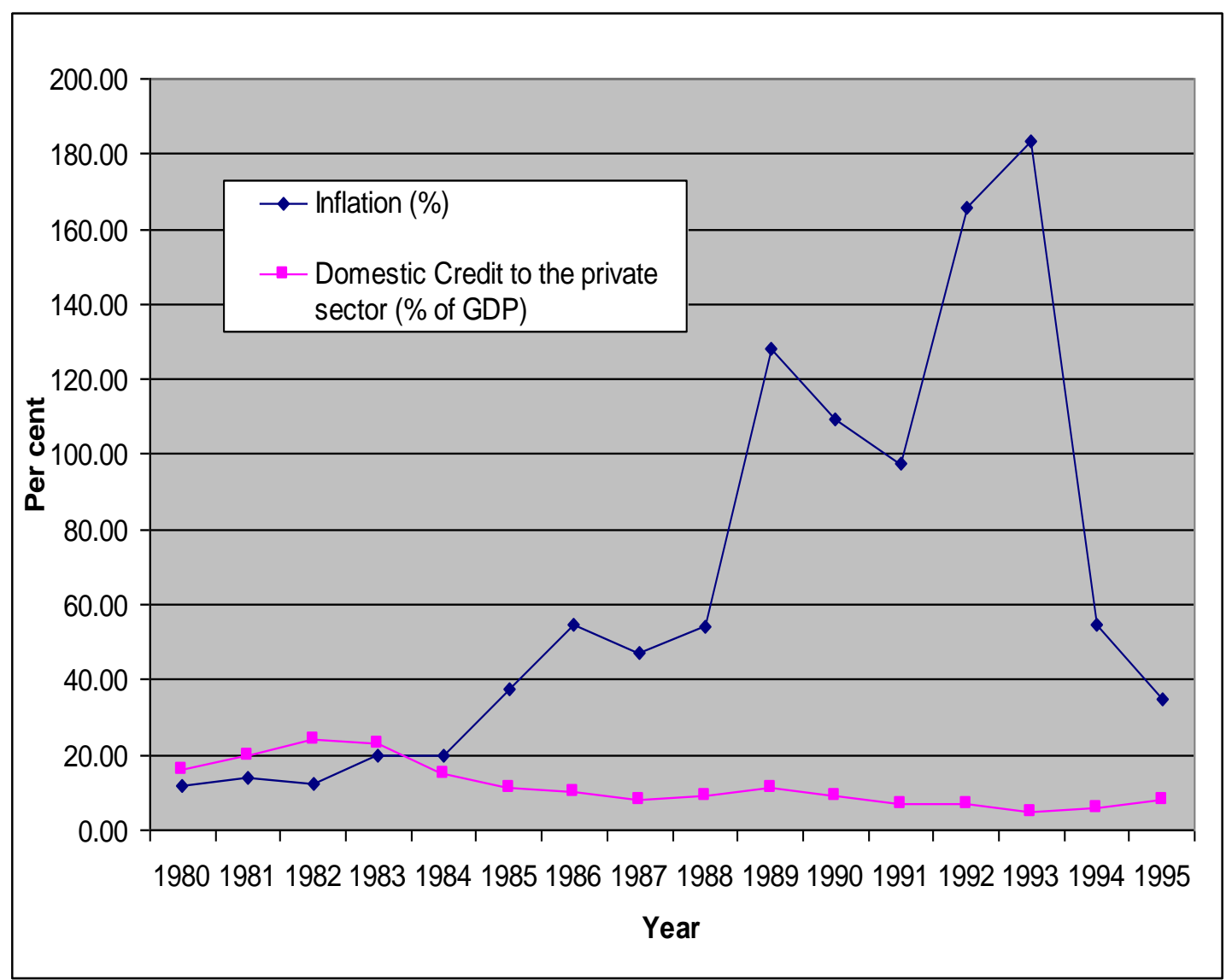

Figure1: The Trends of Inflation and Domestic Credit to the Private Sector in Zambia During the Period 1980-1995 Source: World Development Indicators (2012)

NB: Domestic credit to the private sector (1992) => Author's estimate

\section{ESTIMATION TECHNIQUES AND EMPIRICAL ANALYSIS}

\subsection{The ARDL-bounds Testing Procedure}

The cointegration technique used in this study is based on the recently developed Autoregressive Distributed Lag (ARDL)-bounds testing approach by Perasan et al. (2001). The ARDL-bounds model used in this study can be expressed as follows:

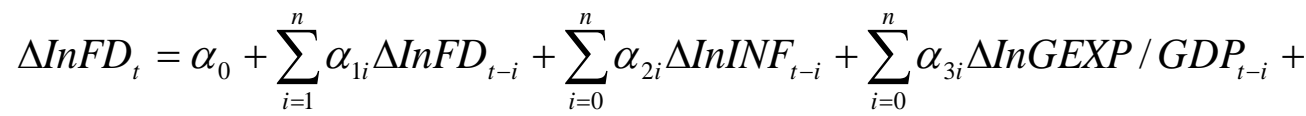

$$
\begin{aligned}
& \sum_{i=0}^{n} \alpha_{4 i} \Delta \operatorname{InTRADE} / G D P_{t-i}+\sum_{i=0}^{n} \alpha_{5 i} \Delta \operatorname{Iny} / N_{t-i}+\alpha_{6} \operatorname{InFD}_{t-1}+\alpha_{7} \operatorname{InINF}_{t-1}
\end{aligned}
$$

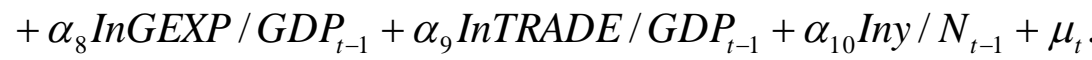

Where: InFD $=\log$ of financial development (gross domestic credit to the ratio of GDP); InINF $=\log$ of consumer inflation; InGEXP/GDP $=\log$ of government expenditure as a percentage of GDP; InTRADE/GDP $=\log$ of total volume of trade as a percentage of GDP; Iny $/ \mathrm{N}=\log$ of per capita GDP; $\mu_{\mathrm{t}}=$ white noise error term; $\Delta=$ first difference operator. 


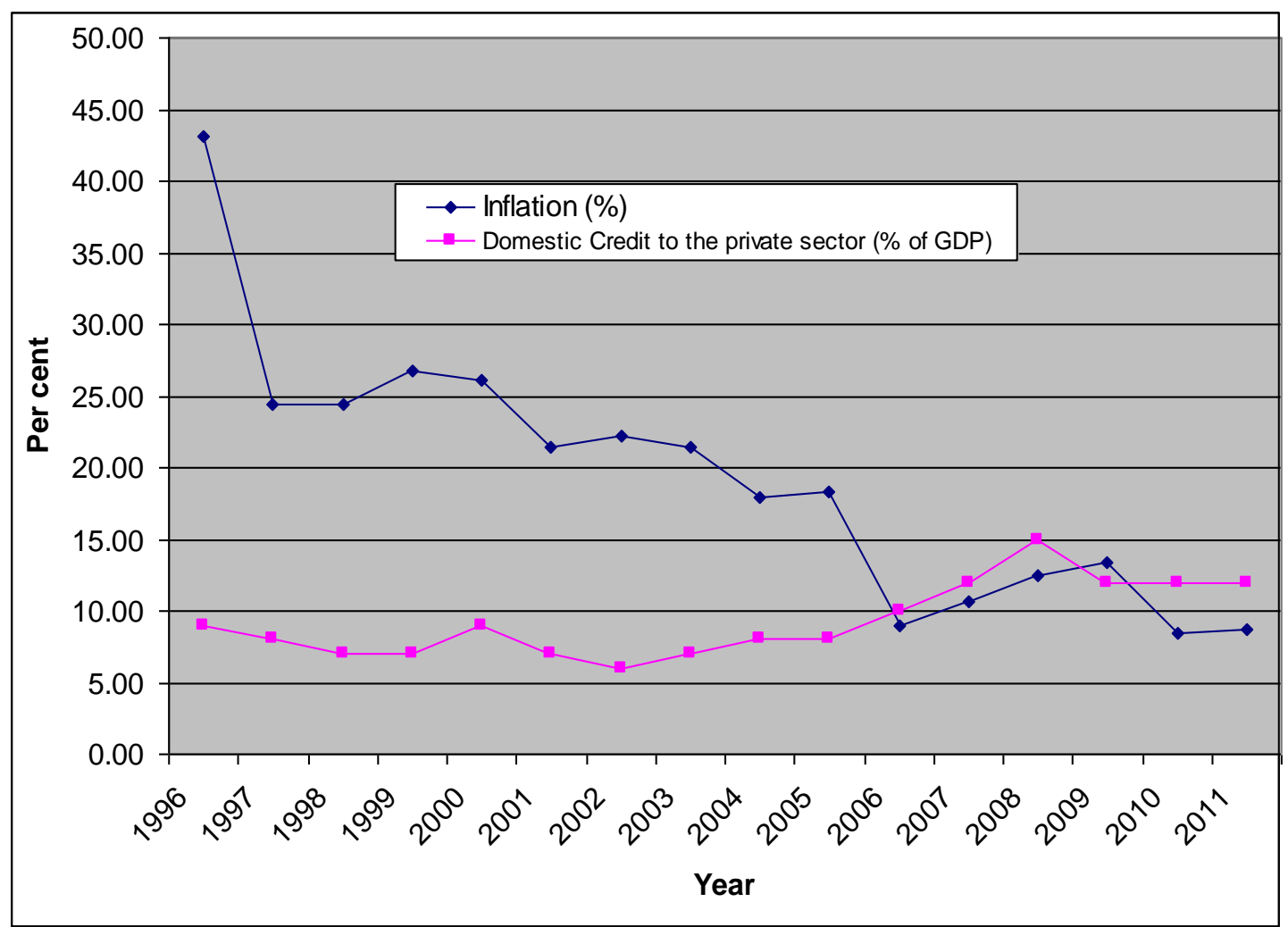

Figure2: The Trends of Inflation and Domestic Credit to the Private Sector in Zambia During the Period 1996-2011 Source: World Development Indicators (2012)

The bounds test involves performing the F-test on the null hypothesis of no cointegration (i.e. Ho: $\alpha=\alpha$ ${ }_{7}=\alpha_{8}=\alpha_{9}=\alpha_{10}=0$ ) against the alternative: $\left.\mathrm{H}_{1}: \alpha_{6} \neq 0 ; \alpha_{7} \neq 0 ; \alpha_{8} \neq 0 ; \alpha{ }_{9} \neq 0 ; \alpha_{10} \neq 0\right)$. When the computed F-statistic exceeds the upper critical bounds value, then the Ho hypothesis is rejected. When the F-statistic is lower than the lower bounds value, then the null hypothesis of no cointegration cannot be rejected. However, when the F-statistic falls within the bounds, the cointegration test becomes inconclusive.

\subsection{Un-Restricted Error-Correction Model}

The error-correction model used in this study is based on the following equation:

$$
\begin{aligned}
& \Delta I n F D_{t}=\alpha_{0}+\sum_{i=1}^{n} \alpha_{1 i} \Delta \operatorname{InINF}_{t-i}+\sum_{i=0}^{n} \alpha_{2 i} \Delta \operatorname{InGEXP} / G D P_{t-i}+\sum_{i=0}^{n} \alpha_{3 i} \Delta \operatorname{InTRADE} / \mathrm{GDP}_{t-i} \\
& +\sum_{i=0}^{n} \alpha_{3 i} \Delta \operatorname{Iny} / N_{t-i}+E C M_{t-1}+\mu_{t}(2)
\end{aligned}
$$

From the estimated UECM, the long-run elasticities are the coefficients of the explanatory variables lagged one period (multiplied by a negative sign) divided by the coefficient of the dependent variable also lagged one period (see Bardsen, 1989).

Where $\mathrm{ECM}_{\mathrm{t}-1}=$ the lagged error-correction term obtained from the long-run equilibrium relationship.

The annual data used in this study, cover the period 1972-2009, and are obtained from the World Economic Outlook (2012) and the World Development Indicators (2012). 


\subsection{Empirical Analysis}

\subsubsection{Stationarity Tests}

Although the ARDL modelling approach does not require unit root tests, it is important to conduct the unit root test, in order to ensure that no variable is integrated of order 2 [I(2)] or higher. This is critical because the ARDL procedure assumes that all variables are either $\mathrm{I}(0)$ or $\mathrm{I}(1)$. If a variable is found to be $\mathrm{I}(2)$, then the computed F-statistics produced by Pesaran et al (2001) are no longer valid.

Table 1: Stationarity Tests of Variables on First Difference

\begin{tabular}{|l|c|c|}
\hline \multicolumn{1}{|c|}{ Variable } & \multicolumn{1}{c|}{ Trend } \\
\hline Phillips-Perron (PP) Test & & $-6.893331^{* * *}$ \\
\hline DLFD & $-4.264645^{* * *}$ & $-5.552732^{* * *}$ \\
\hline DLINF & $-5.132204^{* * *}$ & $-6.682843^{* * *}$ \\
\hline DLGEXP & $-6.767061^{* * *}$ & $-5.504917 * * *$ \\
\hline DLTRADE & $-5.681812^{* * *}$ & $-4.752781^{* * *}$ \\
\hline DLy/N & $-3.433450^{* * *}$ & $-4.366422^{* * *}$ \\
\hline Dickey-Fuller - GLS Test & & $-5.121721^{* * *}$ \\
\hline DLFD & $-3.907373^{* * *}$ & $-6.177645^{* * *}$ \\
\hline DLINF & $-4.143095^{* * *}$ & $-5.160053^{* * *}$ \\
\hline DLGEXP & $-5.518295^{* * *}$ & $-4.365729 * * *$ \\
\hline DLTRADE & $-3.916636^{* * *}$ & \\
\hline DLy/N & $-3.263080^{* * *}$ & \\
\hline
\end{tabular}

Note:

1) The truncation lag for the PP tests is based on Newey and West (1987) bandwidth.

2) $* * *$ denotes $1 \%$ level of significance.

3) Critical values for Dickey-Fuller GLS test are based on Elliot-Rothenberg-Stock (1996, Table 1).

The most frequently used unit root test is based on the Augmented Dickey-Fuller test - a parametric approach originally proposed by Dickey and Fuller $(1979,1981)$. Unfortunately, it has been proved, using Monte Carlo simulations, that the power of the ADF test is very low. To overcome this problem, the semi-parametric Philips-Perron test, as proposed by Phillips and Perron (1988), and the Dicky-Fuller generalised least square detrending (DF-GLS) test proposed by Elliot et al. (1996) have been used in this study. The results of the stationarity tests on differenced variables are presented in Table 1.

The results reported in Table 1 show that all the variables are stationary after being differenced once. This, therefore, confirms that no variable in the financial development equation is integrated of order two or higher.

\subsubsection{Bounds Test for Cointegration}

The first step of the ARDL-bounds testing approach involves obtaining the order of lags on the first differenced variables from the unrestricted financial development model - using the Akaike Information Criterion (AIC) and the Schwartz Bayesian Criterion (SBC). The results of the AIC and SBC tests (not reported here) show that the optimal lag of FD equation is lag 2. The second step involves applying the bounds F-test to the financial development equation, in order to establish whether a long-run relationship exists between FD, INF, GEXP/GDP, TRADE/GDP and $y / N$. The results of the bounds test are reported in Table 2.

Table 2: ARDL-Bounds Test for Cointegration Analysis

\begin{tabular}{|l|c|c|}
\hline Computed F- Statistic: 4.2267** & \multicolumn{2}{c|}{$\mathrm{I}(1)$} \\
\hline Critical Bounds (1\%) & 3.74 & 5.06 \\
Critical Bounds (5\%) & 2.86 & 4.01 \\
Critical Bounds (10\%) & 2.45 & 3.52 \\
\hline
\end{tabular}

Notes:

1) Critical values are taken from Table C1 (iii) of Pesaran et al. (2001): Unrestricted intercept and no trend

2) ** denotes $5 \%$ level of significance

C 2012 The Clute Institute http://www.cluteinstitute.com/ 
The results of the Bounds test presented in Table 2 indicate that the computed F-statistic (4.2267) exceeds the upper bound critical value (4.01) at the 5\% level of significance. This indicates that there is a stable long-run relationship between the financial development variable and its determinants, namely: inflation rate, government expenditure, trade and economic growth. Having confirmed the existence of a cointegrating relationship between financial development and its explanatory variables, the next step is to examine the marginal impact of the explanatory variables on financial development. The results of the long-run analysis are reported in Table 3 .

Table 3: Long-Run Results - Financial Development Equation

\begin{tabular}{|l|c|c|l|}
\hline \multicolumn{4}{|c|}{$\begin{array}{c}\text { Dependent Variable: LFD } \\
\text { Method: Least Squares }\end{array}$} \\
\hline \multicolumn{1}{|c|}{ Variable } & Coefficient & Std. Error & \multicolumn{1}{c|}{ t-Statistic } \\
\hline LINF & -0.242340 & 0.042544 & $-5.696221^{* * *}$ \\
\hline LGEXP/GDP & 0.101131 & 0.126655 & 0.798474 \\
\hline LTRADE/GDP & -0.707837 & 0.361544 & $-1.957816^{*}$ \\
\hline Ly/N & 1.489018 & 0.255301 & $5.832392^{* * *}$ \\
\hline C & -15.01784 & 3.646978 & -4.117886 \\
\hline
\end{tabular}

Note: $* * *$ and $*$ denote $1 \%$ and $10 \%$ level of significance, respectively.

The results reported in Table 3 show that there is a long run negative relationship between inflation and financial development in Zambia. In other words, an increase in inflation impedes on the development of the financial sector in Zambia. This finding is supported by the coefficient of the inflation rate in the financial development equation, which is negative and statistically significant at the $1 \%$ level. The results also show that economic growth has a positive impact on the development of the financial sector - as supported by the coefficient of the economic growth in the financial development equation, which is positive and statistically significant at the $1 \%$ level. The results of the short-run relationships based on ECM are reported in Table 4.

Table 4: Modelling DLFD by OLS

\begin{tabular}{|l|c|c|c|}
\hline \multicolumn{1}{|c|}{ Variable } & Coefficient & t-value & PartR $^{\mathbf{2}}$ \\
\hline Constant & -0.018810 & -0.659 & 0.0282 \\
\hline DLFD-3 & -0.44493 & $-2.585^{* *}$ & 0.3081 \\
\hline DLINF & -0.10140 & -1.268 & 0.0968 \\
\hline DLINF-1 & -0.28000 & $-3.600^{* * *}$ & 0.4636 \\
\hline DLINF-2 & -0.20987 & $-2.749^{* *}$ & 0.3351 \\
\hline DLINF-3 & -0.03530 & -0.358 & 0.0085 \\
\hline DLy/N & -0.28963 & -0.365 & 0.0088 \\
\hline DLy/N-1 & 1.07490 & 1.422 & 0.1188 \\
\hline DLy/N-3 & 0.57759 & 0.839 & 0.0448 \\
\hline DLTRADE & 0.36039 & 1.121 & 0.0773 \\
\hline DLTRADE-1 & -0.56386 & $-1.832^{*}$ & 0.1828 \\
\hline DLGEXP-2 & 0.07000 & 0.546 & 0.0195 \\
\hline ECM-1 & -0.59636 & $-2.473^{* *}$ & 0.2897 \\
\hline
\end{tabular}

$\mathrm{R}^{2}=0.733583 \mathrm{~F}(12,15)=3.4419[0.0133] \alpha=0.141626 \mathrm{DW}=2.04$

$\mathrm{RSS}=0.3008697674$

Note: $* * *, * *$ and $*$ denote $1 \%, 5 \%$ and $10 \%$ level of significance, respectively.

The battery of tests performed for the above model shows that the model generally conforms to the basic diagnostic tests. The model does not suffer from serial correlation, neither is the model misspecified, nor is the choice of functional form incorrect. The normality of the residuals is not rejected; and therefore, the reliability of the "t" values is confirmed. The residuals are also shown to be homoscedastic.

The results reported in Table 4 show that the error-correction term has the correct negative sign and is statistically significant. The significant coefficient of error-correction term in the financial development equation indicates a strong feedback effect of deviation of financial development function from its long-run growth path. The results also show that there is a negative relationship between inflation and financial development in Zambia. This 
finding is supported by the coefficients of the lag values of inflation (i.e. DLINF-1 and DLINF-2) in the financial development equation, which are negative and statistically significant.

Since the stability of the financial development equation is crucial in a study of this nature, it is also important to test whether the estimated financial development function has shifted over time. For this purpose, the cumulative sum of residual (CUSUM) and the cumulative sum of squares of recursive residuals (CUSUMSQ) class of tests have been employed. The results of the CUSUM and CUSUMSQ tests are reported in Figures 3 and 4.

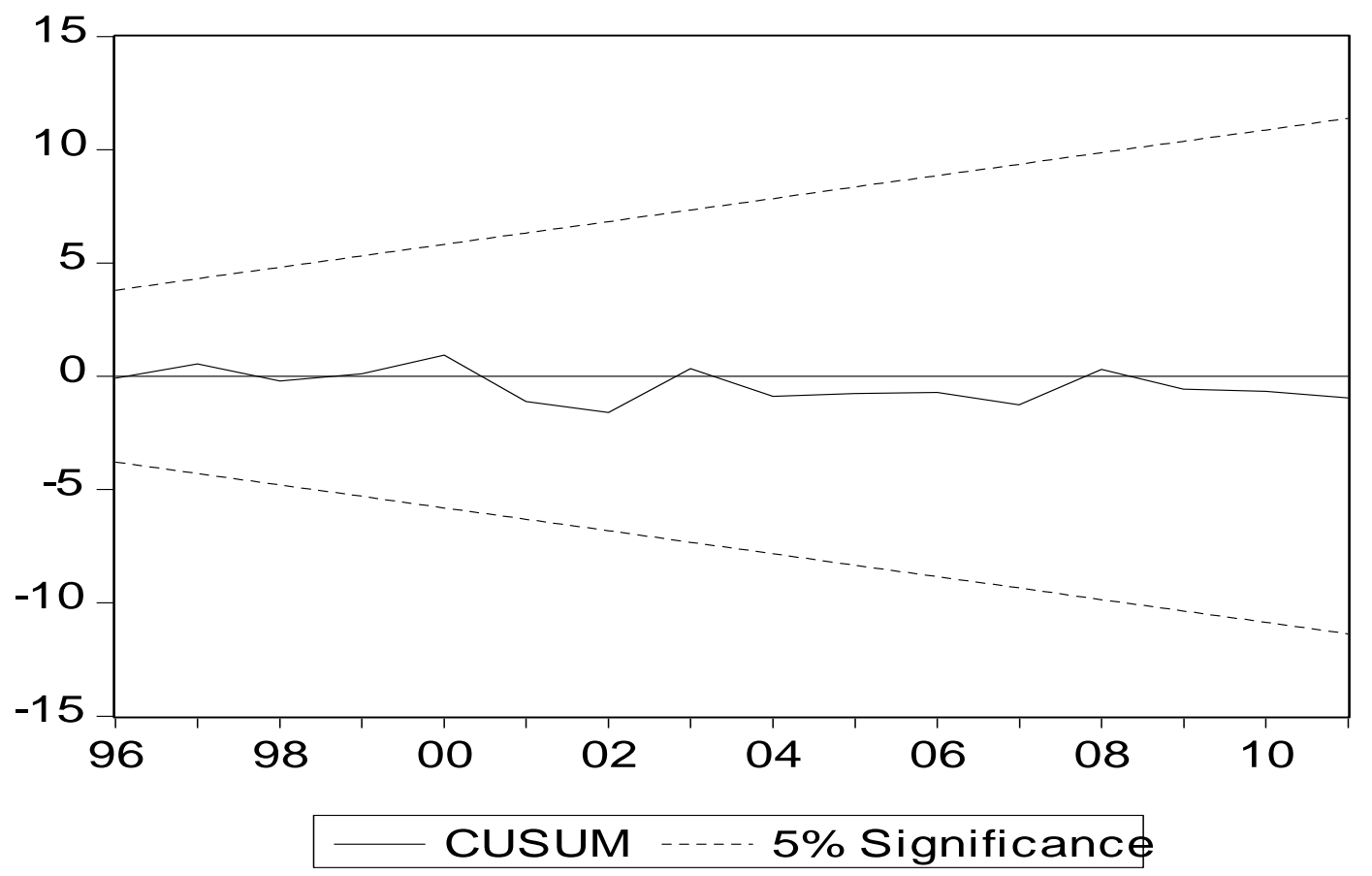

Figure 3: Plot of Cumulative Sum of Recursive Residuals 


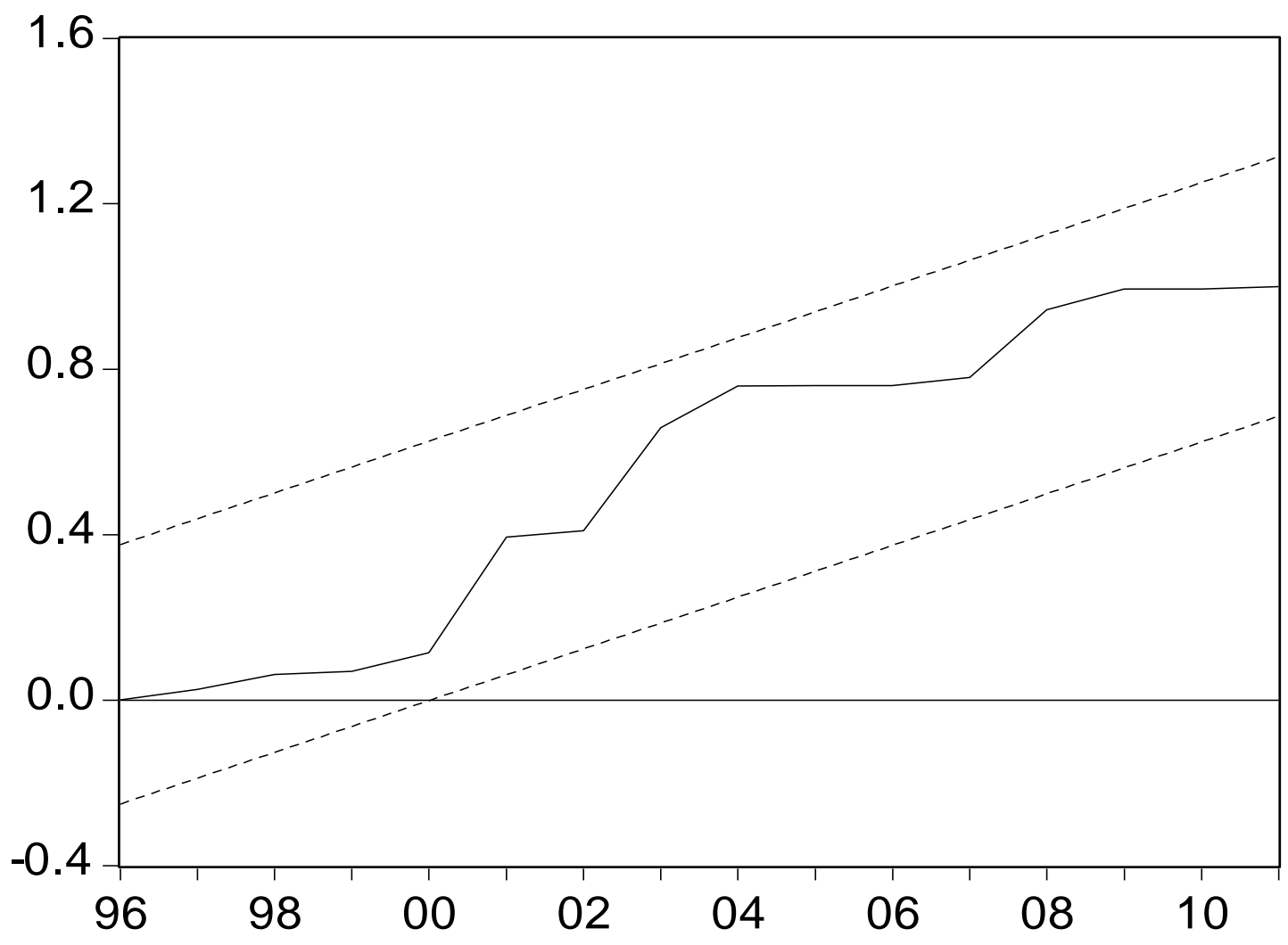

\section{CUSUM of Squares $\cdots 5 \%$ Significance}

Figure 4: Plot of Cumulative Sum of Squares of Recursive Residuals

As can be seen from Figures 3 and 4, the CUSUM and CUSUM Square tests for stability indicate that the parameters are stable during the sample period.

\section{CONCLUSION}

In this paper, we examined the impact of inflation in Zambia during the period 1980-2011. The study uses a standard financial development function to examine this linkage. The financial development is proxied by the domestic credit to the private sector (as a percentage of GDP). In order to ensure that the financial development model is fully specified, the financial sector development is regressed on inflation, economic growth (proxied by GDP per capita), trade volume (as a percentage of GDP) and government spending (as a percentage of GDP). Given the weaknesses associated with Engle-Granger residual-based cointegration technique (proposed by Engle and Granger, 1987) and the maximum- likelihood test (proposed by Johansen, 1988; 1991 and Johansen and Juselius, 1990), the current study uses the newly developed ARDL-bounds testing approach to examine the impact of inflation on financial development in Zambia. The ARDL modelling approach was originally introduced by Perasan and Shin (1999) and later extended by Perasan et al. (2001). The main advantage of the ARDL-bounds testing approach is that unlike other cointegration techniques, the ARDL-bounds test is suitable, even when the sample size is small. The results of this study show that there is a long-run relationship between inflation and financial development in Zambia. The results also show that there is a distinctly negative relationship between inflation and financial development. The results apply, irrespective of whether the model is estimated in the short run or in the long run. 


\section{AUTHOR INFORMATION}

Nicholas M. Odhiambo, University of South Africa, South Africa. E-mail: odhianm@unisa.ac.za / nmbaya99@yahoo.com

\section{REFERENCES}

1. Boyd, JH, Levine, R. and Smith, B.D., 2001, "The Impact of Inflation on Financial Sector Performance", Journal of Monetary Economics 47, pp. 221-248.

2. Dickey, D., and W. Fuller (1979), "Distribution of the estimators for autoregressive time series with a unit root", Journal of the American Statistical Association 74: 427-431.

3. Dickey, D., and W. Fuller (1981), "Likelihood ratio statistics for autoregressive time series with a unit root", Econometrica 49: 057-72.

4. Elliot, G., Rothenberg, T., Stock J. (1996), "Efficient Tests for An Autoregressive Unit Root", Econometrica 64, 813-36.

5. Engle, R.F. and Granger, C.J. (1987), “Cointegration and Error-correction - Representation, Estimation and Testing”, Econometrica 55 (2): 251-78.

6. $\quad$ English, W.B., 1999, "Inflation and Financial Sector Size", Journal of Monetary Economics 44, pp. 379400 .

7. Haslag, J. and Koo, J., 1999, "Financial Repression, Financial Development and Economic Growth", Federal Reserve Bank of Dallas, Working Paper No. 99-02.

8. Huybens, E. and Smith, B., 1998, "Financial Market Frictions, Monetary Policy, and Capital Accumulation in a Small Open Economy", Journal of Economic Theory 81: 353-400.

9. Huybens, E. and Smith, B., 1999, "Inflation, Financial Markets, and Long-Run Real Activity", Journal of Monetary Economics 43: 283-315.

10. Ikhide, Sylvanus (1992), "Financial Deepening, Credit Availability and the Efficiency of Investment: Evidence of Selected African Countries", Development Research Paper Series, Research Paper No 2.

11. IMF (2012), World Economic Outlook, Washington, D. C, IMF.

12. Johansen, S. 1988. Statistical analysis of cointegration vectors. Journal of Economic Dynamics and Control 12: 231-54:

13. Johansen, S. (1991), "Estimation and Hypothesis Testing of Cointegration Vectors in Gaussian vector Autoregressive Models", Econometrica, 59: 1551-80:

14. Johansen, S. and Juselius, K. (1990), "Maximum Likelihood Estimation and Inference on Cointegration with Applications to the Demand for Money", Oxford Bulletin of Economics and Statistics 52: 169-210:

15. Khan, M.S. and Senhadji, S.A. (2001), "Threshold Effects in the Relationship between Inflation and Growth", IMF Staff Papers, Vol. 48, No. 1.

16. Newey, W.K. and West, K.D (1987), “A Simple, Positive Semi-Definite, Heteroskedasticity and Autocorrelation Consistent Covariance Matrix", Econometrica 55: 703-8.

17. Odhiambo, NM (2005), "Financial liberalisation and financial deepening: Evidence from three SSA countries", African Review of Money Finance and Banking (Savings and Development Supplement): 5-23.

18. Odhiambo, N.M. (2008), "Financial Depth, Savings and Economic Growth in Kenya: A Dynamic Causal Linkage", Economic Modelling 25(4), 704-713.

19. Pesaran, M., Pesaran, B., 1997. Working with Microfit 4.0: Interactive economic analysis, Oxford University Press, Oxford.

20. Pesaran, M., Shin, Y. and Smith, R. (2001), "Bounds Testing Approaches to the Analysis of Level Relationships", Journal of Applied Econometrics 16, 289-326.

21. Phillips, P. C. B., and P. Perron. 1988. Testing for a unit root in time series regression. Biometrika 75: 335 346.

22. Simatele, M. 2004. Financial sector reforms and monetary policy in Zambia. PhD dissertation, Goteborg University.

23. World Bank (2012), World Development Indicators, The World Bank, Washington, D. C. 


\section{APPENDIX}

Appendix 1: The Trends of GDP Per Capita During the Period 1980-2010

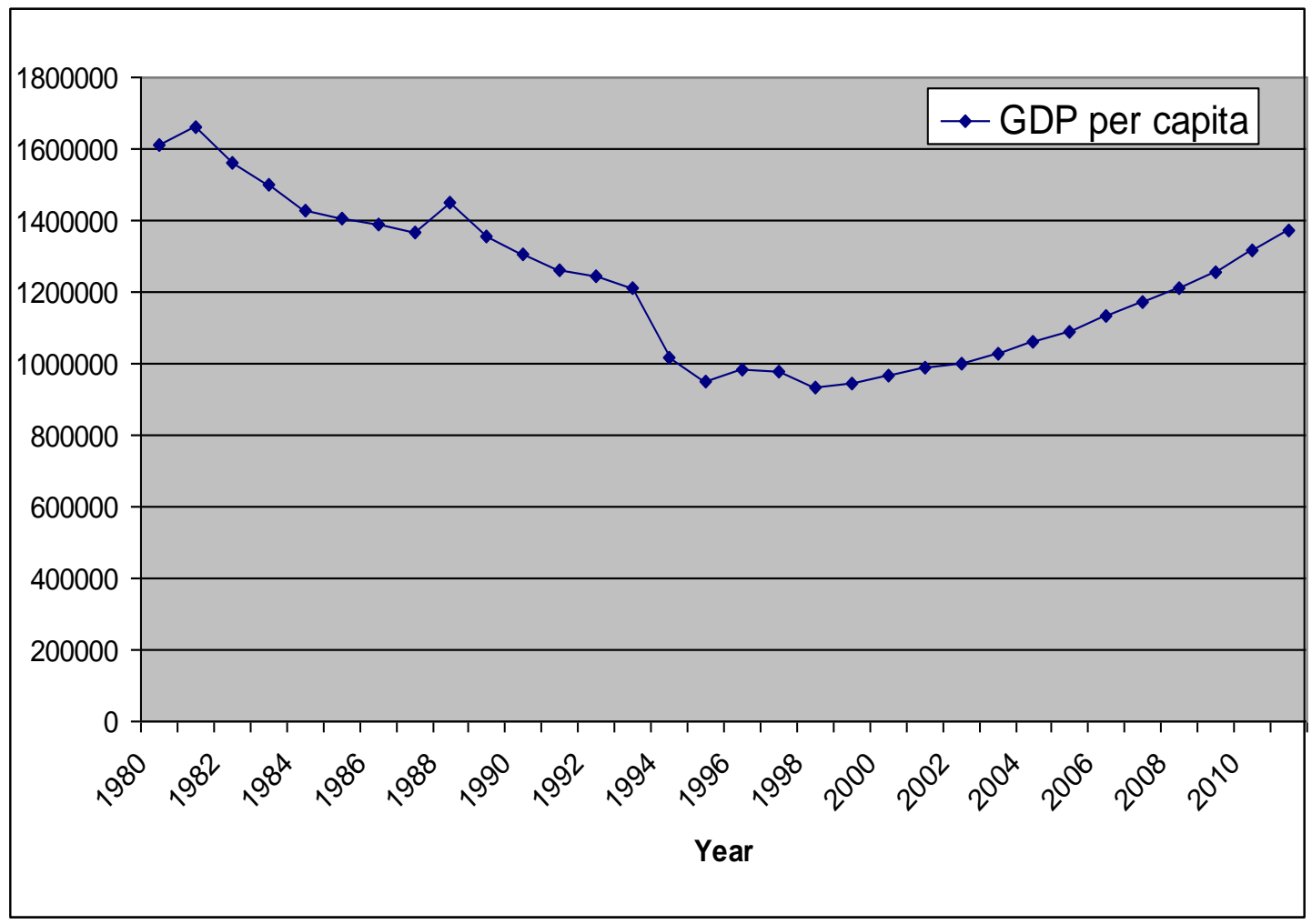


Appendix 2: The Trends of Trade Volume as a \% of GDP During the Period 1980-2010

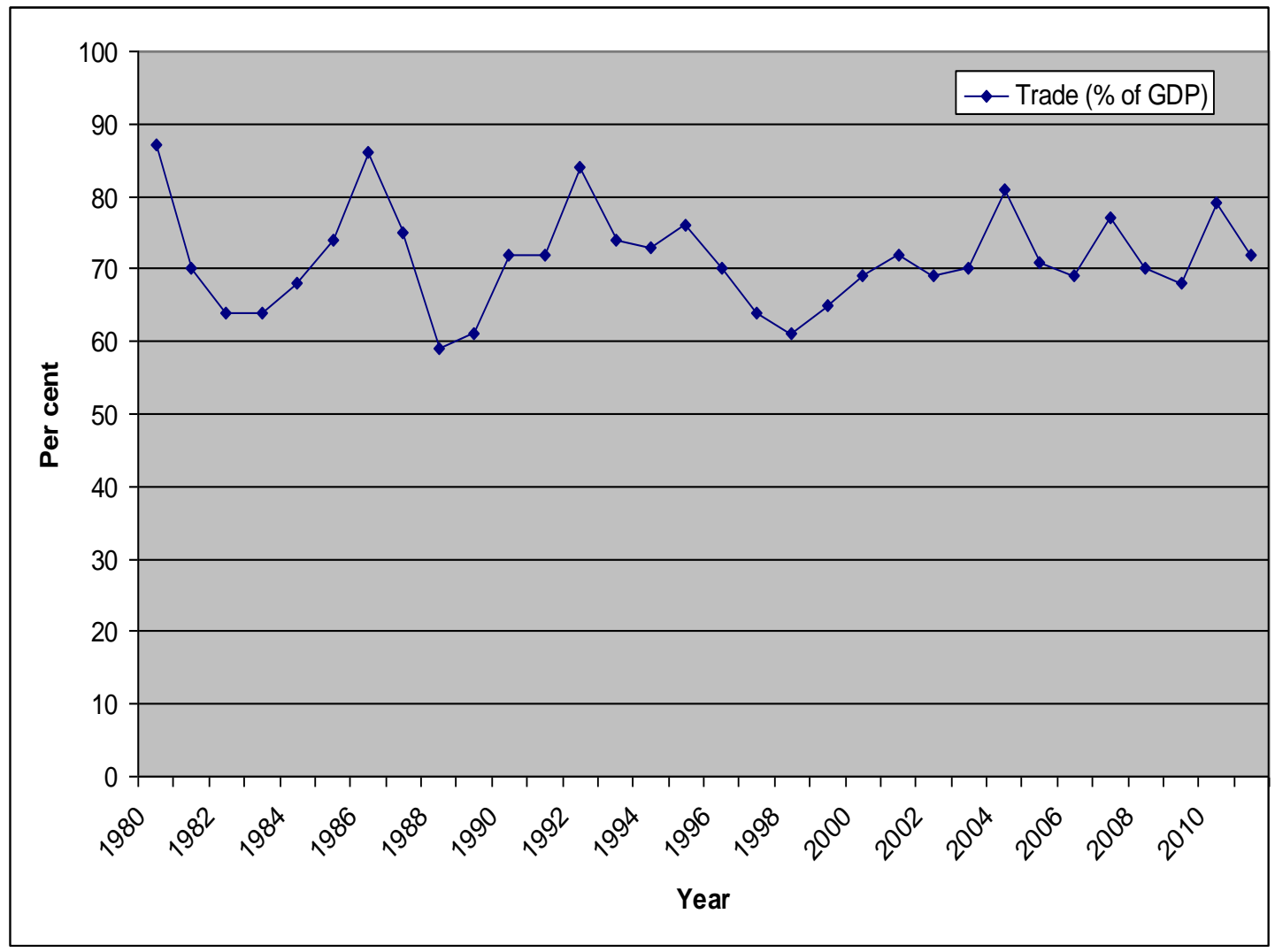


Appendix 3: The Trends of Government Expenditure as a \% of GDP During the Period 1980- 2010

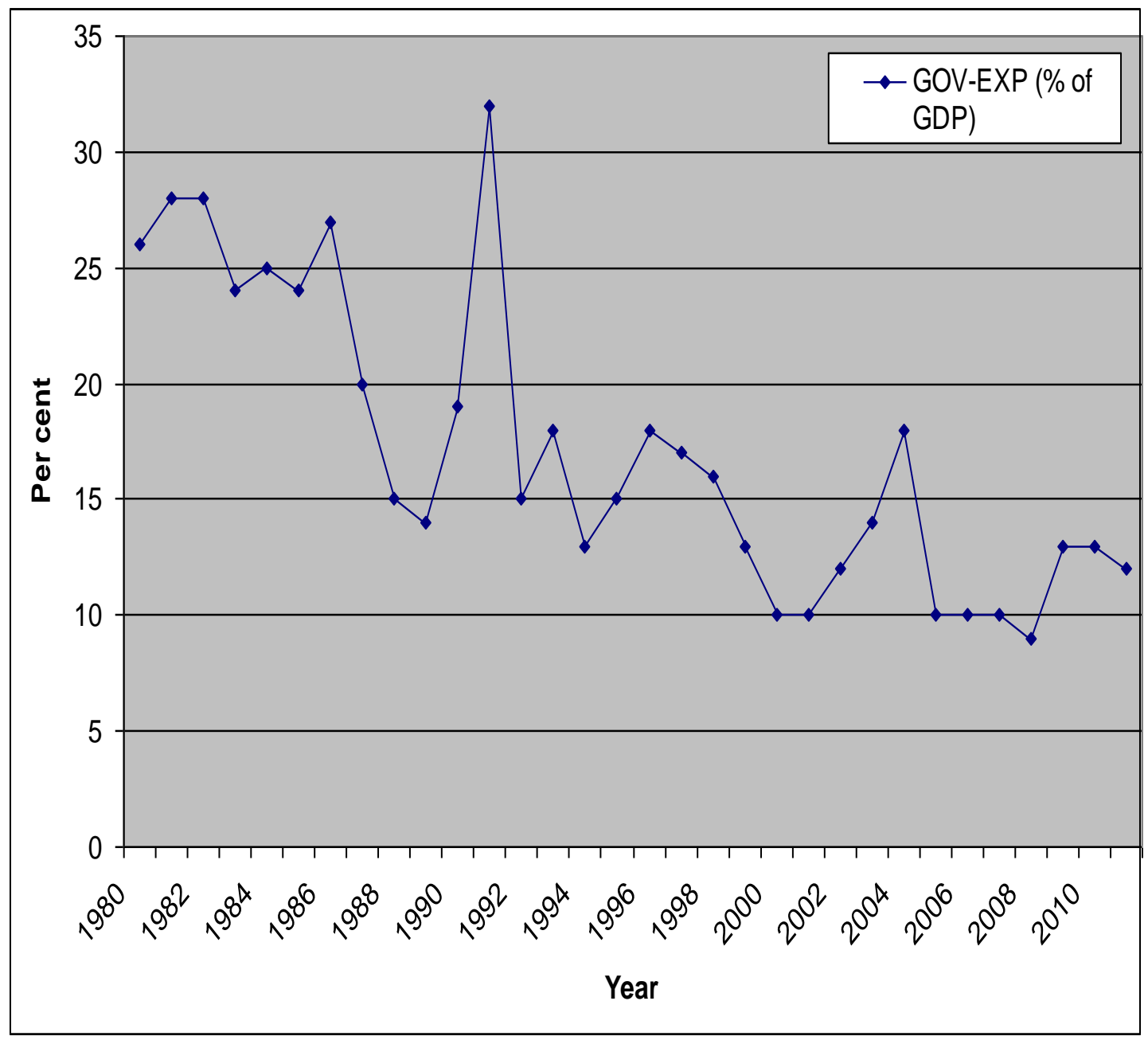

